Article

\title{
Shelf-Life Evaluation of Ingredient Combinations and Technologies for Use in Pet Food Formulations
}

\author{
Madison P. Wagoner ${ }^{1}$, Marc R. Presume ${ }^{2}$, Moses E. Chilenje ${ }^{2}$, Gerardo A. Abascal-Ponciano ${ }^{2}$, Jorge L. Sandoval ${ }^{2}$, \\ Hunter R. Smith ${ }^{1}$, Tristan M. Reyes ${ }^{1}$, Barney S. Wilborn ${ }^{1}$, Justin A. Dunavant ${ }^{2}$, Robert P. Mason ${ }^{3}$, Eric K. Altom ${ }^{3}$, \\ Charles W. Starkey ${ }^{2}$ and Jason T. Sawyer $1, * \mathbb{D}$ \\ 1 Department of Animal Sciences, Auburn University, Auburn, AL 36849, USA; \\ mpw0035@auburn.edu (M.P.W.); hzs0101@auburn.edu (H.R.S.); tzr0039@auburn.edu (T.M.R.); \\ wilbobs@auburn.edu (B.S.W.) \\ 2 Department of Poultry Science, Auburn University, Auburn, AL 36849, USA; mrp0067@auburn.edu (M.R.P.); \\ oamoseo@gmail.com (M.E.C.); gaa0029@auburn.edu (G.A.A.-P.); jls0152@auburn.edu (J.L.S.); \\ jad0075@auburn.edu (J.A.D.); cws0031@auburn.edu (C.W.S.) \\ 3 Balchem Animal Nutrition and Health, Balchem Corp., New Hampton, NY 10958, USA; \\ RMason@balchem.com (R.P.M.); EAltom@balchem.com (E.K.A.) \\ * Correspondence: jts0109@auburn.edu; Tel.: +1-334-844-1517; Fax: +1-334-844-1519
}

check for updates

Citation: Wagoner, M.P.; Presume, M.R.; Chilenje, M.E.;

Abascal-Ponciano, G.A.; Sandoval, J.L.; Smith, H.R.; Reyes, T.M.; Wilborn, B.S.; Dunavant, J.A.; Mason, R.P.; et al. Shelf-Life Evaluation of Ingredient Combinations and Technologies for Use in Pet Food Formulations. Animals 2022, 12, 152. https://doi.org/10.3390/ani12020152

Academic Editor: Giacomo Biagi

Received: 30 November 2021

Accepted: 7 January 2022

Published: 8 January 2022

Publisher's Note: MDPI stays neutral with regard to jurisdictional claims in published maps and institutional affiliations.

Copyright: (C) 2022 by the authors. Licensee MDPI, Basel, Switzerland. This article is an open access article distributed under the terms and conditions of the Creative Commons Attribution (CC BY) license (https:// creativecommons.org/licenses/by/ $4.0 /)$.
Simple Summary: Creation of new meat-based pet food and pet treats continues to grow at a steady annual rate within the pet food industry. Poultry co-products are often overlooked due to their poor quality and low customer acceptance. However, poultry co-products pose great potential and added value to the pet food industry. Two of the most common poultry co-products (wooden breast and carcass frames) often directed towards pet food were used in a fresh pet food formulation. Due to variations in meat quality because of the wooden breast and carcass frames, a hydrocolloid was utilized to improve fresh pet food characteristics. A hydrocolloid is a type of protein that when added to meat products aids with binding and stabilization of the pet food. For the current study, the combination of sodium alginate and encapsulated calcium lactate pentahydrate (ALGIN) was used. Due to the perceived poor quality of wooden breast and carcass frames, it is plausible that the addition of hydrocolloids can combat the undesirable characteristics. Results from the current study suggest that the impact of ALGIN in poultry co-product pet food combinations does not severely alter shelf-life characteristics of a fresh pet food. However, the inclusion of varying amounts of wooden breast and ground carcass frame can impart a greater impact on shelf-life characteristics in fresh pet food by altering surface color and lipid oxidation.

Abstract: Poultry co-product chicken frames (CF) and wooden breast (WB) along with ingredient technology use may bring enhanced value to the pet food industry. Therefore, the current study focused on evaluating CF and WB combinations along with sodium alginate and encapsulated calcium lactate pentahydrate (ALGIN) inclusion within a fresh pet food formulation under simulated shelf-life conditions. Fresh chicken frames (CF) and boneless-skinless wooden breast (WB) were ground and allocated randomly to one of ten treatment combinations with either 0.5 or $1.0 \%$ added ALGIN. Ground treatments were placed into a form and fill vacuum package and stored using a reach-in refrigerated case for 21 days. Packages were evaluated for instrumental surface color, lipid oxidation, water activity, and $\mathrm{pH}$ on days 1,3, 7, 14 and 21 of the display. Packages of pet food were lighter, less red, and more yellow $(p<0.05)$ with increasing percentages of CF regardless of ALGIN inclusion, whereas $\mathrm{pH}$ was greater $(p<0.05)$ and lipid oxidation was less $(p<0.05)$ with increasing percentage of WB. Water activity increased $(p<0.05)$ when WB and ALGIN inclusion increased. The current results suggest that the use of ALGIN in a poultry co-product pet food formulation can improve shelf-life characteristics such as surface color and lipid oxidation in fresh pet food.

Keywords: algin; ground frame; hydrocolloid; pet food; shelf-life; wooden breast 


\section{Introduction}

Creative development and availability of meat-based food and treats for pets in the retail space continue to increase at a rapid pace. According to American Pet Products Association, sales within the U.S. Market in 2020 for pet food and treats alone was $\$ 42.0$ billion and the estimated sales for 2021 is to be $\$ 44.1$ billion [1]. Due to the variety of pet food options, pet food customers are provided with an almost limitless number of options based on packaging, price, size of the product, ingredient preference, nutritional benefits, and pet breed options. A focus of the pet food industry has traditionally relied on animal by-products from the rendering industry. All animal material that is considered inedible for human consumption is further processed for animal agriculture purposes such as fertilizer, animal feed and pet food treats and/or food. Type of animal by-products that are rendered include offal, fat, blood, bones, meat trimmings and viscera. Within the poultry meat industry, inedible by-products account for approximately $28 \%$ of the live weight of a broiler chicken [2]. Poultry co-products are often undervalued throughout the meat industry due to their poor quality and low customer acceptance. However, it is plausible that these co-products could be a potential key component in adding value to the pet food industry.

The poultry industry has struggled with a muscle myopathy identified as wooden breast $(\mathrm{WB})$ resulting in tough muscle texture. This muscle abnormality has and continues to have a negative impact economically on the broiler industry [3]. WB is characterized as a myopathy that presents an overtly harder chicken breast, with sections being swollen and pale resulting in decreased meat quality, yield, and consumer/customer acceptance [4]. Initially, visual characterization of WB was identified by the white striations throughout the breast meat [5] because of excessive accumulation of lipids and connective tissue [6]. Severely affected chicken breasts caused by muscle fiber degeneration have been downgraded by the processor and directed to be further processed within the meat and poultry industry that may include deli meats, sausages, emulsified products, and even pet food. Pet food buyers are influenced by similar organoleptic attributes when buying food for their pets such as aroma, texture, and color. In addition, uniformity and branding are important drivers that may suggest higher quality. Studies have reported that pet food customers are highly influenced by the appearance of the pet food or treat and a darker brown color seems to influence pet owner purchasing intent [7]. Another poultry by-product gaining consideration for use in possible pet food formulations is chicken frames (CF) because of it is nutritional properties [8]. However, when nutritionally evaluating chicken meat and bone meals, these co-products consist of a greater protein level (50 percent) and contain more saturated fatty acids when compared to other rendered meat [9].

Due to the low quality of WB and CF, it is plausible that the addition of hydrocolloids to these meat co-products may aid in creating more desirable characteristics making the co-products suitable for fresh pet food and pet treat applications. Hydrocolloids are used to define a range of proteins and polysaccharides that contain an affinity for water. Hydrocolloids are used throughout the meat and food industry to aid in a variety of formulation functions that include gelling, binding, coating, thickening, stabilization of $\mathrm{pH}$, enhanced heat resistance, salt tolerance, as well as reduce undesirable effects caused when reducing fat and salt content [10-12]. Interestingly, gelling of food products via hydrocolloids allows for the product to become more stable [13]. Out of the wide range of hydrocolloids within the meat and food industry today, the combination of sodium alginate and encapsulated calcium lactate pentahydrate (ALGIN) was selected for the current study. Sodium alginate has been commonly used within the food industry in the development of functional food products for human and companion animal consumption. Sodium alginate is an irreversible hydrocolloid that is derived from brown algae, a polysaccharide that is composed of 1-4, $\beta$-D mannuronic acid and $\alpha$-L guluronic acid sugar residues $[14,15]$. An advantage of using the algin/calcium gel combination, has reported improvements in binding cooked or raw meat products and can prevent the potential negative effects of added salt on product quality [16-18]. To our knowledge, there is very little literature about the effects of ALGIN when included in poultry co-product formulations such as CF 
and WB with the intended purpose of creating pet food products. Therefore, the aim of this study was to evaluate the inclusion rate of ALGIN on meat co-product formulations of CF and WB and subsequent impact on fresh pet food shelf-life characteristics.

\section{Materials and Methods}

\subsection{Raw Materials}

Boneless-skinless wooden breast (WB) meat and de-boned chicken frames (CF) were purchased from a commercial poultry processing facility in North Alabama. Classification of WB was conducted by trained plant personnel at the time of grading using the scoring methods described in [19]: ( $0=$ normal; $1=$ moderate, $2=$ severe; and $3=$ extreme). Fresh, raw materials were transported under refrigerated conditions $\left(2{ }^{\circ} \mathrm{C}\right)$ to the Lambert-Powell Meats Laboratory at Auburn University and stored in the absence of light at $2{ }^{\circ} \mathrm{C}$ for $36 \mathrm{~h}$. Fresh, raw poultry materials WB and CF were ground twice using a commercial meat grinder (Hollymatic 3000, Thompson Meat Machinery, Queensland, Australia). To aid in reducing the surface area of the raw materials, CF was ground once through a $9.52 \mathrm{~mm}$ grinder plate then a second time through a $4.76 \mathrm{~mm}$ grinder plate (SPECO 400, Schiller Park, IL, USA). Fresh boneless-skinless WB meat was ground twice through a $4.76 \mathrm{~mm}$ grinder plate (SPECO 400, Schiller Park, IL, USA). After grinding, ground WB and CF were weighed and randomly allocated to 10 treatment batches $(\mathrm{N}=22.67 \mathrm{~kg} /$ treatment $)$ with two replications ( $n=11.34 \mathrm{~kg} /$ replication). Treatment combinations (Table 1$)$ of WB and $\mathrm{CF}(\mathrm{COMB})$ were mixed in a commercial mixer (AFMG 48, Biro, Marblehead, OH, USA) for 5 min while slowly incorporating sodium alginate and calcium lactate (ALGIN). After mixing, each treatment was portioned into $454 \pm 0.5 \mathrm{~g}$ bricks using a vacuum stuffer (Model VF608plus, Handtmann, Biberach, Germany).

Table 1. Pet food formulations with poultry co-product and ALGIN ${ }^{1}$ inclusion percentages.

\begin{tabular}{ccccccccccc}
\hline & \multicolumn{1}{c}{ Treatments } \\
\hline Ingredients & A & B & C & D & E & F & G & H & I & J \\
\hline Wooden Breast, \% & 0.00 & 0.00 & 25 & 25 & 50 & 50 & 75 & 75 & 100 & 100 \\
Chicken Frame, \% & 100 & 100 & 75 & 75 & 50 & 50 & 25 & 25 & 0.00 & 0.00 \\
Total, \% & 100 & 100 & 100 & 100 & 100 & 100 & 100 & 100 & 100 & 100 \\
ALGIN 1 & & & & & & & & & & \\
Sodium Alginate, \% & 1.00 & 0.50 & 1.00 & 0.50 & 1.00 & 0.50 & 1.00 & 0.50 & 1.00 & 0.50 \\
Calcium Lactate, \% & 0.85 & 0.425 & 0.85 & 0.425 & 0.85 & 0.425 & 0.85 & 0.425 & 0.85 & 0.425 \\
\hline
\end{tabular}

${ }^{1}$ ALGIN is an inclusion percentage (\%) of two functional ingredients, sodium alginate and calcium lactate.

\subsection{Treatment Packaging}

After portioning, fresh pet food bricks were packaged using a Reiser form and fill vacuum packaging machine (Optimus OL0924, Variovac, Zarrentin, Germany). Each package was placed into a commercial film (WINPAK, Winnipeg, MB, Canada) that was comprised of a forming film with a standard barrier consisting of $175 \mu \mathrm{m}$ Nylon, EVOH and enhanced polyethylene coextrusion and a non-forming film layer was comprised of $60 \mu \mathrm{m}$ Nylon, EVOH and polyethylene coextrusion. The oxygen transmission rates (OTR) for the forming and non-forming films were $0.4 \mathrm{cc} / \mathrm{sq} . \mathrm{m} / 24 \mathrm{~h}$ and $1.2 \mathrm{cc} / \mathrm{sq} . \mathrm{m} / 24 \mathrm{~h}$, respectively.

\subsection{Simulated Retail Display Conditions}

Packages of fresh pet food were stored in a pull-door, self-service refrigerated 3 tiered LED lighted display case (Model 178GDC49HCB, Avantco Refrigeration, Lancaster, PA, USA) for up to 21 days. Storage temperatures during the simulated display were monitored using a data-recording device (TD2F, Thermoworks, American Fork, UT, USA) with probes placed within the center of each shelf. Refrigerated case temperatures averaged $2.1 \pm 1.25^{\circ} \mathrm{C}$. The continuous LED (308 lux) lighting of each shelf was measured in the 
display cases with a hand-held light meter (Model ILT10C, International Light Technologies, Peabody, MA, USA). Packages of pet food were distributed evenly across the shelving and rotated daily from top to bottom and front to back within the display cooler to reduce temperature variation and simulate consumer package shifting at the retail counter.

\subsection{Instrumental Color Measurement}

Instrumental color readings were collected by scanning each sample through the packaging [20], at three separate locations on each package using a HunterLab MiniScan XE Plus Colorimeter (Model 45/0-L, Hunter Associates Laboratory Inc., Reston, VA, USA). Color readings $\left(\mathrm{L}^{*}, \mathrm{a}^{*}\right.$ and $\left.\mathrm{b}^{*}\right)$ were recorded using Illuminant D65, a $10^{\circ}$ observer with a $25 \mathrm{~mm}$ diameter aperture using the Commission Internationale de $\mathrm{l}^{\prime}$ Eclairage (CIE L*a* $\mathrm{b}^{*}$ ) color scale [21]. Prior to capturing objective surface color readings for fresh color, the colorimeter was calibrated on each sampling day 1,3,7, 14, and 21 using the standard black and white tiles $\left(\mathrm{L}^{*}, 0=\right.$ black, $100=$ white; $\mathrm{a}^{*},-60=$ green, $+60=$ red; $b^{*},-60=$ blue, and $+60=$ yellow $)$.

\subsection{Thiobarbituric Acid Reactive Substances (TBARS)}

On days $1,3,7$, and 14 of the simulated display period, packages of fresh pet were removed from the display cases and frozen at $-80{ }^{\circ} \mathrm{C}$ until TBARS analysis could be completed. Prior to analysis, samples were placed into a refrigerated cooler $4{ }^{\circ} \mathrm{C}$ and thawed for $12 \mathrm{~h}$. After thawing, pet food was removed from the packaging material and prepared for 2-thiobarbituric acid reactive substance using a modified version [21]. In duplicate, approximately $5 \mathrm{~g}$ of each package was homogenized with $8 \mathrm{~mL}$ of cold $\left(1^{\circ} \mathrm{C}\right)$ of $50 \mathrm{mM}$ phosphate buffer ( $\mathrm{pH}$ of 7.0 at $4{ }^{\circ} \mathrm{C}$ ) that contained $0.1 \%$ ethylenediaminetetraacetic acid, 0.1\% n-propyl gallate, and $2 \mathrm{~mL}$ trichloroacetic acid (Sigma-Aldrich, Saint Louis, MO, USA). After homogenizing, samples were filtered through Whatmann No.4 filter paper and duplicate $2 \mathrm{~mL}$ aliquots of the clear supernatant were transferred into $10 \mathrm{~mL}$ borosilicate tubes, mixed with $2 \mathrm{~mL}$ of $0.02 \mathrm{M}$ 2-thiobarbituric acid reagent (BeanTown Chemical, Hudson, NH, USA), and boiled at $100{ }^{\circ} \mathrm{C}$ for $20 \mathrm{~min}$. Immediately after boiling, tubes were placed into an ice bath for $15 \mathrm{~min}$. Finally, absorbance was measured at $533 \mathrm{~nm}$ with a spectrophotometer (Turner Model—SM110245, Barnstead International, Dubugue, IA, USA) and then multiplied using a factor of 12.21 to derive the TBARS value (mg of malonaldehyde/ $\mathrm{kg}$ of fresh meat) [22]. The value of 12.21 was obtained previously from a standard curve using a known malonaldehyde solution measured across multiple absorbencies.

\subsection{Fresh $p H$ and Water Activity $\left(a_{w}\right)$}

Packages of fresh pet food from each treatment were chosen randomly from the display cabinets on days $1,3,7,14$, and 21 to be analyzed for $\mathrm{pH}$ and water activity $\left(\mathrm{a}_{\mathrm{w}}\right)$. Prior to collecting $\mathrm{pH}$ readings, the $\mathrm{pH}$ meter was calibrated using 2-point standard buffers ( $\mathrm{pH} 4.0$ and 7.0). Duplicate packages from each treatment were opened and using a $\mathrm{pH}$ electrode attached to a pH meter (Model HI199163, Hanna Instruments, Woonsocket, RI, USA) was inserted into the ground pet food. Measurements for $\mathrm{pH}$ were collected in triplicate from each packaged and averaged. For water activity samples, $4 \mathrm{~g}$ of ground pet food was removed from each package in duplicate inserted into the plastic sample container and analyzed using a benchtop water activity meter AUQALAB 4TE (Dew Point Model, METER Group, Inc., Pullman, WA, USA) which uses the dew point principal method [23].

\subsection{Statistical Analysis}

An analysis of variance was computed using a generalized linear mixed model (GLIMMIX) procedure with statistical analysis software (SAS Institute, Inc. Cary, NC, USA) version 9.4. Fixed effects for ground chicken frames (CF) and wooden breast (WB) and ALGIN inclusion percentage along with their interaction were evaluated. Least-squares 
means were computed for all variables, and when significant ( $p \leq 0.05$ ) F-values were observed, least-squares means were separated using pair-wise $t$-tests (PDIFF option).

\section{Results and Discussion}

\subsection{Instrumental Fresh Color}

The combination (COMB) of WB and CF and ALGIN across DAY of simulated display presented an interaction $(p<0.05)$ for instrumental fresh surface color lightness (Table 2$)$. Surface color of pet food packages was lighter $(p<0.05)$ with greater percentages of CF regardless of ALGIN or day of display. However, as the duration of display increased, surface color lightness became darkest $(p<0.05)$ with increasing percentages of WB (Table 2$)$. In addition, an interaction of COMB $\times$ ALGIN $\times$ DAY occurred for instrumental surface color redness (Table 3). Packages of pet food formulations with greater percentages of WB were redder initially $(p<0.05)$, whereas packages of CF remained lighter throughout the entire display period regardless of ALGIN inclusion (Table 3). Lastly, an interactive influence of COMB $\times$ ALGIN $\times$ DAY for surface color yellowness occurred (Table 4). Packages of pet food formulations were more yellow $(p<0.05)$ throughout the entire display period when the percentage of CF was greatest and ALGIN was only $0.5 \%$ within the formulation. Moreover, as the concentration of WB increased, surface $b^{*}$ became greener $(p<0.05)$. Fresh surface color of pet food remains an enigma within the retail market because the intended user of the food is not visually appraising the product in the same manner fresh edible meat products are assessed. However, it is plausible that purchasers of fresh pet food (pet owners) will continue to use surface color as an indicator of wholesome and freshness of pet food constructed with fresh meat ingredients that can deteriorate during a storage period. In a similar study [24] on surface color differences between cooked and raw WB samples with non-affected boneless, skinless, breast fillets, it was reported that the chicken breasts with severe WB can have greater redness ( $\left.a^{*}\right)$ values, which appears consistent with our findings in the current study. In additional studies, it has been determined that boneless, skinless WB fillets often have more connective tissue and a greater percentage of white striations throughout the filet often causing an altered surface color of the meat $[5,24-26]$. It was expected that the formulations with higher percentages of WB would result in greater lightness $\left(\mathrm{L}^{*}\right)$ values due to less muscle myoglobin influence and greater hemorrhagic lesions throughout the affected WB meat. However, the current results indicate lightness $\left(\mathrm{L}^{*}\right)$ values for treatment combinations containing more WB in the formulations darker, redder and greener. A similar reported that WB fillets had significantly greater $(p<0.05)$ lightness values $\left(\mathrm{L}^{*}\right)$ and yellowness values $\left(\mathrm{b}^{*}\right)$, which are inconsistent with our findings [25]. The inconsistency in surface color results may be attributed to the addition of $C F$, severity of WB within the COMB, but does not suggest that ALGIN imparted surface color changes throughout the simulated display period.

Table 2. Interactive effect of COMB $\times$ ALGIN $\times$ DAY on instrumental fresh color lightness $\left(\mathrm{L}^{*}\right)^{1}$ of fresh pet food formulations during a simulated retail display.

\begin{tabular}{|c|c|c|c|c|c|c|c|c|c|c|c|}
\hline \multicolumn{12}{|c|}{$\mathrm{COMB}^{2}$} \\
\hline & \multicolumn{2}{|c|}{$100 \mathrm{CF}: 00 \mathrm{WB}$} & \multicolumn{2}{|c|}{75 CF:25 WB } & \multicolumn{2}{|c|}{50 CF:50 WB } & \multicolumn{2}{|c|}{25 CF:75 WB } & \multicolumn{2}{|c|}{00 CF:100 WB } & \\
\hline \multicolumn{12}{|c|}{ ALGIN $^{3}$} \\
\hline & 0.5 & 1.0 & 0.5 & 1.0 & 0.5 & 1.0 & 0.5 & 1.0 & 0.5 & 1.0 & SEM \\
\hline Day $1^{4}$ & $62.88^{\mathrm{cd}}$ & $62.68^{\mathrm{cd}}$ & 57.54 hij & $57.04^{\mathrm{ijk}}$ & $56.13^{\mathrm{klm}}$ & 54.91 nopqr & $53.89^{\text {stuv }}$ & 52.34 xyz & 52.63 wxy & 51.70 yza* $^{*}$ & 0.4993 \\
\hline Day 3 & $62.63^{\mathrm{cd}}$ & $63.27^{c}$ & 58.00 ghi & $57.29^{\mathrm{ij}}$ & $56.61^{\mathrm{jkl}}$ & $55.23^{\text {mnop }}$ & 54.98 nopq & $53.72^{\text {tuv }}$ & $54.45^{\text {opqrstu }}$ & 54.25 pqrstu & 0.4993 \\
\hline Day 7 & $59.17^{\mathrm{f}}$ & $60.22^{e}$ & $53.78^{\text {tuv }}$ & $54.64^{\text {opqrst }}$ & $52.06^{\mathrm{xyz}}$ & $51.76^{\text {yza }^{*}}$ & $51.35^{\mathrm{za}^{*}}$ & $50.81^{a^{*} b^{*}}$ & $50.83^{\mathrm{a}^{*} \mathrm{~b}^{*}}$ & $50.06^{\mathrm{b}^{*}}$ & 0.4993 \\
\hline Day 14 & $64.80^{\mathrm{b}}$ & $66.03^{a}$ & $59.15^{f}$ & $58.83^{\mathrm{fg}}$ & $58.47^{\mathrm{fgh}}$ & $57.02^{\mathrm{ijk}}$ & 54.81 nopqrs & $55.42 \mathrm{mno}$ & 53.70 tuv & $53.98^{\text {rst }}$ & 0.4993 \\
\hline Day 21 & $62.09 \mathrm{~d}$ & $64.71^{b}$ & $57.01 \mathrm{jk}$ & $57.14^{\mathrm{ij}}$ & $55.64^{1 \mathrm{mn}}$ & $54.58^{\text {opqrst }}$ & $53.48^{\text {uvw }}$ & $54.04 \mathrm{qrstu}$ & 54.35 pqrstu & $52.96^{\mathrm{vwx}}$ & 0.4993 \\
\hline
\end{tabular}

${ }^{1}$ Lightness $\left(\mathrm{L}^{*}\right.$ ) values are a measure of darkness to lightness (larger value indicates a lighter color). ${ }^{2} \mathrm{COMB}$ is the raw material formulation of ground chicken frame (CF) and/or boneless-skinless wooden breast (WB). ${ }^{3}$ ALGIN is the inclusion percentage (\%) of two functional ingredients, sodium alginate and calcium lactate. ${ }^{4}$ Simulated storage conditions consisted of reach-in refrigerated cabinet maintained at $4{ }^{\circ} \mathrm{C}$. ${ }^{\mathrm{a}-\mathrm{b}^{*}}$ All mean values lacking common superscripts differ $(p<0.05)$. 
Table 3. Interactive effect of COMB $\times$ ALGIN $\times$ DAY on instrumental fresh color redness $\left(a^{*}\right)^{1}$ of fresh ${ }^{1}$ Lightness $\left(\mathrm{L}^{*}\right)$ values are a measure of darkness to lightness (larger value indicates a lighter color).

\begin{tabular}{|c|c|c|c|c|c|c|c|c|c|c|c|}
\hline \multicolumn{12}{|c|}{$\mathrm{COMB}^{2}$} \\
\hline & \multicolumn{2}{|c|}{$100 \mathrm{CF}: 00 \mathrm{WB}$} & \multicolumn{2}{|c|}{75 CF:25 WB } & \multicolumn{2}{|c|}{50 CF:50 WB } & \multicolumn{2}{|c|}{25 CF:75 WB } & \multicolumn{2}{|c|}{00 CF:100 WB } & \\
\hline \multicolumn{12}{|c|}{ ALGIN $^{3}$} \\
\hline & 0.50 & 1.00 & 0.50 & 1.00 & 0.50 & 1.00 & 0.50 & 1.00 & 0.50 & 1.00 & SEM \\
\hline Day $1^{4}$ & $6.42^{\mathrm{a}^{*}}$ & $6.144^{\mathrm{a}^{*}}$ & $9.86^{w}$ & $9.91 \mathrm{w}$ & $11.18^{\text {nopqrs }}$ & $11.43^{\text {jklmnop }}$ & $11.98^{\text {defghi }}$ & $12.32^{\mathrm{bcd}}$ & $12.61^{\mathrm{ab}}$ & $12.87^{\mathrm{a}}$ & 0.2603 \\
\hline Day 3 & $6.58^{\mathrm{za}^{*}}$ & $6.30^{\mathrm{a}^{*}}$ & $10.03^{\mathrm{w}}$ & $10.17^{\mathrm{vw}}$ & $11.28^{\text {lmnopqr }}$ & 11.81 efghijk & $12.17^{\text {bcdefg }}$ & $12.07^{\text {cdefghi }}$ & $12.12^{\text {bcdefg }}$ & $12.21^{\text {bcdef }}$ & 0.2603 \\
\hline Day 7 & $7.11^{\mathrm{y}}$ & $7.07^{y x}$ & $10.65^{\text {tuv }}$ & $10.27^{\text {uvw }}$ & 11.79 fghijkl & 11.60 hijlkmno & 12.01 cdefgh & $12.25^{\text {bcdefg }}$ & 11.69 ghijklmn & $12.46^{\mathrm{abcd}}$ & 0.2603 \\
\hline Day 14 & $7.80^{x}$ & $7.09 \mathrm{yz}$ & $10.77^{\text {rstu }}$ & 11.27 mnopqr & $11.76^{\text {fghijklm }}$ & 11.87 efghij & 11.94 defghij & $11.88^{\text {efghij }}$ & $12.53^{a b c}$ & $11.56^{\text {ijklmnop }}$ & 0.2603 \\
\hline Day 21 & $6.51^{\mathrm{a}^{*}}$ & $6.27 \mathrm{a}^{*}$ & $9.86^{\mathrm{w}}$ & $9.95^{w}$ & $10.85^{\mathrm{qrst}}$ & 11.30 klmnopq & 11.19 nopqrs & 11.09 opqrst & 11.07 pqrst & $10.75^{\text {stu }}$ & 0.2603 \\
\hline \multicolumn{12}{|c|}{$\begin{array}{l}{ }^{1} \text { Lightness }\left(\mathrm{L}^{*}\right) \text { values are a measure of darkness to lightness (larger value indicates a lighter color). }{ }^{2} \mathrm{COMB} \text { is the } \\
\text { raw material formulation of ground chicken frame }(\mathrm{CF}) \text { and/or boneless-skinless wooden breast }(\mathrm{WB}) .{ }^{3} \mathrm{ALGIN} \\
\text { is the inclusion percentage }(\%) \text { of two functional ingredients, sodium alginate and calcium lactate. }{ }^{4} \text { Simulated } \\
\text { storage conditions consisted of reach-in refrigerated cabinet maintained at } 4{ }^{\circ} \mathrm{C}^{\mathrm{a}-\mathrm{b}^{*} \text { All mean values lacking }} \\
\text { common superscripts differ }(p<0.05) \text {. }\end{array}$} \\
\hline
\end{tabular}

Table 4. Interactive effect of COMB $\times$ ALGIN $\times$ DAY on instrumental fresh color yellowness $\left(b^{*}\right)^{1}$ of pet food formulations during a simulated retail display.

\begin{tabular}{|c|c|c|c|c|c|c|c|c|c|c|c|}
\hline \multicolumn{12}{|c|}{$\mathrm{COMB}^{2}$} \\
\hline & \multicolumn{2}{|c|}{$100 \mathrm{CF}: 00 \mathrm{WB}$} & \multicolumn{2}{|c|}{75 CF:25 WB } & \multicolumn{2}{|c|}{50 CF:50 WB } & \multicolumn{2}{|c|}{25 CF:75 WB } & \multicolumn{2}{|c|}{00 CF:100 WB } & \\
\hline \multicolumn{12}{|c|}{ ALGIN $^{3}$} \\
\hline & 0.5 & 1.0 & 0.5 & 1.0 & 0.5 & 1.0 & 0.5 & 1.0 & 0.5 & 1.0 & SEM \\
\hline Day $1^{4}$ & $21.73^{\text {cde }}$ & $20.78^{\mathrm{f}}$ & $18.37^{\text {hi }}$ & $18.21^{\mathrm{hi}}$ & 16.41 pqrs & $16.92^{\text {nop }}$ & $15.84^{\text {tuv }}$ & $15.15^{x y}$ & $15.73^{\text {uvw }}$ & $15.24^{\text {wxy }}$ & 0.2853 \\
\hline Day 3 & $22.09 \mathrm{bcd}$ & $21.57^{\text {de }}$ & $18.48^{\mathrm{h}}$ & $18.52^{h}$ & 17.02 mno & $17.27^{l m n}$ & $16.60^{\circ p q}$ & $15.42 \mathrm{vwx}$ & $15.71^{\text {uvw }}$ & $15.46^{\mathrm{vwx}}$ & 0.2853 \\
\hline Day 7 & $21.47^{\mathrm{e}}$ & $21.35^{\mathrm{e}}$ & 18.04 hij & $17.49 \mathrm{jklm}$ & 16.33 qrst & 16.38 pqrst & $16.15^{\text {rstu }}$ & 15.02 xy & $14.84^{x y}$ & $15.13^{x y}$ & 0.2853 \\
\hline Day 14 & $23.70^{\mathrm{a}}$ & $22.57^{b}$ & $19.57^{g}$ & $19.61 \mathrm{~g}$ & $17.59 \mathrm{jkl}$ & $17.62^{\mathrm{jkl}}$ & $17.85^{\mathrm{ijk}}$ & 16.41 pqrs & $16.91^{\text {nop }}$ & 16.59 opqr & 0.2853 \\
\hline Day 21 & $22.25^{b c}$ & 21.29 ef & $18.56^{\mathrm{h}}$ & $18.46^{\mathrm{h}}$ & $17.35^{\mathrm{klmn}}$ & $17.15^{\text {lmno }}$ & $16.87^{\text {nopq }}$ & 15.89 stuv & $15.50^{\mathrm{vwx}}$ & 16.34 qrst & 0.2853 \\
\hline
\end{tabular}

1 Yellowness $\left(b^{*}\right)$ values are a measure of darkness to lightness (larger value indicates a more yellow color). ${ }^{2} \mathrm{COMB}$ is the raw material formulation of ground chicken frame (CF) and/or boneless-skinless wooden breast (WB). ${ }^{3}$ ALGIN is the inclusion percentage (\%) of two functional ingredients, sodium alginate and calcium lactate. ${ }^{4}$ Simulated storage conditions consisted of reach-in cabinet coolers maintained at $4{ }^{\circ} \mathrm{C}$. ${ }^{\mathrm{a}-\mathrm{y}}$ All mean values lacking common superscripts differ $(p<0.05)$.

\subsection{Thiobarbituric Acid Reactive Substances (TBARS)}

An interaction $(p<0.05)$ of COMB $\times$ ALGIN $\times$ DAY for TBARS values occurred during the simulated retail display period (Table 5). As a result of fresh pet food quality declining throughout the display period, TBARS values were only measured through 14 days of the simulated display. TBARS values were greatest $(p<0.05)$ on day 14 when ALGIN and WB combinations were 1.0 and $100 \%$, respectively. With limited results available from previous studies, the values from the current study provide a foundation to lipid oxidation changes that may occur during storage of fresh pet food. Previous lipid oxidation findings for WB have suggested that oxidation can be variable [27], whereas frozen storage of cooked chicken sausage formulated with WB can range from 0.14 to $2.00 \mathrm{mg}$ malonaldehyde/kg [28]. Countless studies in chicken [29,30] and beef [31,32] suggest TBARS values may exceed $3 \mathrm{mg}$ of malonaldehyde $/ \mathrm{kg}$ in fresh or cooked meat samples. Current values for TBARS values align with previous studies and provide a baseline for future studies. Consumer perception of meat products for wholesomeness and freshness at the time of use may be partly influenced by lipid oxidation [33]. However, it is necessary that additional research on fresh pet food shelf-life using various ingredient technologies that may or may not improve lipid oxidation be investigated. 
Table 5. Interactive effect of COMB $\times$ ALGIN $\times$ DAY on TBARS $^{1}$ value of pet food formulations during a simulated retail display.

\begin{tabular}{|c|c|c|c|c|c|c|c|c|c|c|c|}
\hline \multicolumn{12}{|c|}{$\mathrm{COMB}^{2}$} \\
\hline & \multicolumn{2}{|c|}{$100 \mathrm{CF}: 00 \mathrm{WB}$} & \multicolumn{2}{|c|}{75 CF:25 WB } & \multicolumn{2}{|c|}{$50 \mathrm{CF}: 50 \mathrm{WB}$} & \multicolumn{2}{|c|}{25 CF:75 WB } & \multicolumn{2}{|c|}{00 CF:100 WB } & \\
\hline \multicolumn{12}{|c|}{ ALGIN $^{3}$} \\
\hline & 0.5 & 1.0 & 0.5 & 1.0 & 0.5 & 1.0 & 0.5 & 1.0 & 0.5 & 1.0 & SEM \\
\hline Day $1^{4}$ & $1.87^{\text {efghij }}$ & $1.72^{\text {hijk }}$ & $1.88^{\text {efghij }}$ & $1.85^{\text {efghhij }}$ & 1.92 efghi & 1.79 fghij & $2.53^{\mathrm{abcd}}$ & $1.71^{\text {hijk }}$ & $1.65^{\text {hijk }}$ & $0.84^{1}$ & 0.3042 \\
\hline Day 3 & $2.69^{a b c}$ & 1.77 fghij & 1.79 fghij & 1.80 fghij & $2.73^{a b c}$ & 1.87 efghij & $1.83^{\text {fghij }}$ & $1.35 \mathrm{ijkl}$ & $1.29 \mathrm{jkl}$ & 1.60 hijk & 0.3042 \\
\hline Day 7 & 1.89 efghij & 1.71 hijk & 2.37 bcdef & $2.34^{\text {bcdefg }}$ & $2.95^{\mathrm{ab}}$ & $1.15^{\mathrm{lk}}$ & $2.46^{\text {abcde }}$ & $2.19^{\text {cdefgh }}$ & $0.89^{1}$ & $1.67^{\text {hijk }}$ & 0.3042 \\
\hline Day 14 & $2.56^{\mathrm{abcd}}$ & $2.46^{\text {abcde }}$ & 1.97 defgh & $1.87^{\text {efghhij }}$ & $1.64^{\text {hijk }}$ & $1.98^{\text {defgh }}$ & 1.74 ghijk & $1.82^{\text {fghij }}$ & $0.87^{1}$ & $3.05^{\mathrm{a}}$ & 0.3042 \\
\hline
\end{tabular}

${ }^{1}$ 2-Thiobarbituric acid reactive substance (TBARS) are a measure of lipid oxidation, with a larger value indicating a greater amount of oxidation (mg malonaldehyde $/ \mathrm{kg}^{-1}$ of fresh meat). ${ }^{2} \mathrm{COMB}$ is the raw material formulation of ground chicken frame (CF) and/or boneless-skinless wooden breast (WB). ${ }^{3}$ ALGIN is the inclusion percentage $(\%)$ of two functional ingredients, sodium alginate and calcium lactate. ${ }^{4}$ Simulated storage conditions consisted of reach-in cabinet coolers maintained at $4{ }^{\circ} \mathrm{C}$. ${ }^{\text {a-l }}$ Mean values lacking common superscripts differ $(p<0.05)$.

\subsection{Fresh Pet Food $p H$ Values}

There was an interactive $(p<0.05)$ effect of COMB $\times$ ALGIN $\times$ DAY on $\mathrm{pH}$ values of fresh pet food during a simulated retail display (Table 6). Pet food containing more than $75 \% \mathrm{WB}$ in the formulation resulted in greater $(p<0.05) \mathrm{pH}$ values throughout the 21 day simulated retail period. It has been reported that $\mathrm{WB}$ tends to have greater $\mathrm{pH}$ values because of muscle degeneration and implications on glycogen content minimizing lactic acid formation in postmortem muscle [34-36]. It has been noted that $\mathrm{CF} \mathrm{pH}$ ranges tend to fall within 6.5 to 6.9 [37]. It is plausible that the variation noted in surface color of the current study are attributed to the influences of fresh $\mathrm{pH}$ values.

Table 6. Interactive effect of COMB $\times$ ALGIN $\times$ DAY on $\mathrm{pH}$ of pet food formulations during a simulated retail display.

\begin{tabular}{|c|c|c|c|c|c|c|c|c|c|c|c|}
\hline \multicolumn{12}{|c|}{$\mathrm{COMB}^{1}$} \\
\hline & \multicolumn{2}{|c|}{$100 \mathrm{CF}: 00 \mathrm{WB}$} & \multicolumn{2}{|c|}{75 CF:25 WB } & \multicolumn{2}{|c|}{50 CF:50 WB } & \multicolumn{2}{|c|}{25 CF:75 WB } & \multicolumn{2}{|c|}{00 CF:100 WB } & \\
\hline \multicolumn{12}{|c|}{ ALGIN $^{2}$} \\
\hline & 0.5 & 1.0 & 0.5 & 1.0 & 0.5 & 1.0 & 0.5 & 1.0 & 0.5 & 1.0 & SEM \\
\hline Day $1^{3}$ & $6.13^{\text {stu }}$ & $6.01^{\text {tuv }}$ & $6.48^{\mathrm{ijklmno}}$ & $6.52^{\mathrm{ijkl}}$ & $6.84^{\mathrm{cde}}$ & $6.76^{\text {defg }}$ & $7.06^{b}$ & $6.92^{\mathrm{bcd}}$ & $7.41^{\mathrm{a}}$ & $7.38^{a}$ & 0.0824 \\
\hline Day 3 & $6.10^{\text {stu }}$ & $6.16^{\mathrm{qrstu}}$ & $6.49^{\mathrm{ijklmn}}$ & 6.39 klmnop & 6.59 ghij & $6.62^{\text {fghi }}$ & $6.84^{\text {cde }}$ & 6.69 efgh & $6.82^{\text {cde }}$ & $6.98^{b c}$ & 0.0824 \\
\hline Day 7 & $5.81^{\mathrm{xyz}}$ & $5.80^{x y z}$ & 5.89 wxy & 5.88 wxyz & $6.12^{\text {stu }}$ & $5.93^{\mathrm{vwx}}$ & 6.25 pqrs & $6.36^{1 \mathrm{mnop}}$ & $6.511^{\mathrm{ijklm}}$ & $6.39^{\text {klmnop }}$ & 0.0824 \\
\hline Day 14 & $5.86^{x y z}$ & $5.75 \mathrm{yz}$ & $6.04^{\text {tuvw }}$ & $6.01^{\text {tuv }}$ & $6.15^{\text {rstu }}$ & $6.15^{\text {rstu }}$ & $6.44^{\mathrm{jklmno}}$ & 6.22 pqrst & 6.35 mnop & 6.39 klmnop & 0.0824 \\
\hline Day 21 & $6.01^{\text {tuvw }}$ & $5.72^{z}$ & 6.53 ijk & 6.32 opqr & $6.02^{\text {uvw }}$ & $6.77^{\text {def }}$ & $6.33^{\text {nopq }}$ & $6.35^{\text {mnop }}$ & $6.58^{\text {hij }}$ & $6.34^{\text {nop }}$ & 0.0824 \\
\hline
\end{tabular}

${ }^{1} \mathrm{COMB}$ is the raw material formulation of ground chicken frame (GF) and/or boneless-skinless wooden breast (WB). ${ }^{2}$ ALGIN is the inclusion percentage (\%) of two functional ingredients, sodium alginate and calcium lactate. ${ }^{3}$ Simulated storage conditions consisted of reach-in cabinet coolers maintained at $4{ }^{\circ} \mathrm{C}$. ${ }^{\mathrm{a}-\mathrm{z}}$ All mean values lacking common superscripts differ $(p<0.05)$.

\subsection{Water Activity $\left(a_{w}\right)$}

There was no interactive $(p>0.05)$ impact of COMB $\times$ ALGIN $\times$ DAY on water activity during the simulated retail display. However, an interactive influence of COMB $\times$ ALGIN (Table 7) on water activity occurred. Water activity increased with increasing usage of ALGIN and percentage of WB in the formulation. As expected, ALGIN improved water holding capacity as WB inclusion increased. It is known [38] that water holding capacity is less in WB leading to further implications on water activity. In addition, there was a COMB $\times$ DAY interaction $(p<0.05)$ on water activity (Table 8 ). Ground fresh pet food with a greater percentage of $\mathrm{WB}$ resulted in greater water activity throughout the simulated retail display. Lastly, the interactive $(p<0.05)$ effect of ALGIN $\times$ DAY on water activity provides further support that the use of hydrocolloids in a meat system can aid water retention (Table 9). At the conclusion (day 21) of simulated retail display, water activity was greater $(p<0.05)$ in fresh pet food containing $1.0 \%$ ALGIN. Previous results support the use of hydrocolloids in a meat system for improving water retention [39]. 
Table 7. Interactive effect of COMB $\times$ ALGIN on water activity $\left(a_{w}\right)$ of pet food formulations during a simulated retail display.

\begin{tabular}{ccccccc}
\hline \multicolumn{7}{c}{ COMB $^{\mathbf{1}}$} \\
\hline & $\mathbf{1 0 0}$ CF:00 WB & 75 CF:25 WB & 50 CF:50 WB & 25 CF:75 WB & 00 CF:100 WB & SEM \\
\hline AGLIN $^{2}$ 0.5 & $0.994^{\mathrm{dc}}$ & $0.993^{\mathrm{e}}$ & $0.993^{\mathrm{de}}$ & $0.994^{\mathrm{dc}}$ & $0.995^{\mathrm{bc}}$ & 0.000476 \\
ALGIN 1.0 $^{\mathrm{e}}$ & $0.993^{\mathrm{e}}$ & $0.994^{\mathrm{dc}}$ & $0.993^{\mathrm{de}}$ & $0.996^{\mathrm{a}}$ & $0.995^{\mathrm{ab}}$ & 0.000476 \\
\hline
\end{tabular}

${ }^{1} \mathrm{COMB}$ is the raw material formulation of ground chicken frame (CF) and/or boneless-skinless wooden breast (WB). ${ }^{2}$ ALGIN is the inclusion percentage (\%) of two functional ingredients, sodium alginate and calcium lactate. a-e Mean values lacking common superscripts differ $(p<0.05)$.

Table 8. Interactive effect of COMB $\times$ DAY on water activity $\left(a_{w}\right)$ of pet food formulations during a simulated display.

\begin{tabular}{|c|c|c|c|c|c|c|}
\hline \multicolumn{7}{|c|}{$\mathrm{COMB}^{1}$} \\
\hline & $100 \mathrm{CF}: 00 \mathrm{WB}$ & 75 CF:25 WB & 50 CF:50 WB & 25 CF:75 WB & 00 CF:100 WB & SEM \\
\hline Day $1^{2}$ & $0.992^{\mathrm{ijk}}$ & $0.992^{\mathrm{jkl}}$ & $0.991^{1}$ & 0.993 ghij & 0.993 fghij & 0.000753 \\
\hline Day 3 & $0.996^{b}$ & $0.996^{b c d}$ & $0.996^{b c}$ & $0.997^{a b}$ & $0.998^{a}$ & 0.000753 \\
\hline Day 7 & 0.993 ghij & $0.992^{\mathrm{ijk}}$ & $0.992^{\mathrm{ijk}}$ & $0.994^{\text {fghij }}$ & $0.994^{\text {defg }}$ & 0.000753 \\
\hline Day 14 & $0.991^{1}$ & $0.991^{\mathrm{kl}}$ & $0.993^{\text {hijk }}$ & 0.994 efghi & 0.994 efghi & 0.000753 \\
\hline Day 21 & 0.993 fghij & 0.995 efgh & $0.995^{\text {cdef }}$ & $0.997^{a b}$ & 0.995 cde & 0.000753 \\
\hline
\end{tabular}

${ }^{1} \mathrm{COMB}$ is the raw material formulation of ground chicken frame (CF) and/or boneless-skinless wooden breast (WB). ${ }^{2}$ Simulated storage conditions consisted of reach-in cabinet coolers maintained at $4{ }^{\circ} \mathrm{C} .{ }^{\mathrm{a}-1}$ Mean values lacking common superscripts differ $(p<0.05)$.

Table 9. Interactive effect of ALGIN $\times$ DAY on water activity $\left(a_{w}\right)$ on pet food formulations during a simulated retail display.

\begin{tabular}{ccccccc}
\hline \multicolumn{7}{c}{ DAY } \\
\hline & $\mathbf{1}$ & $\mathbf{3}$ & $\mathbf{7}$ & $\mathbf{1 4}$ & $\mathbf{2 1}$ & SEM \\
\hline ALGIN $^{1}$ 0.5 & $0.993^{\text {ef }}$ & $0.997^{\mathrm{a}}$ & $0.993^{\mathrm{de}}$ & $0.992^{\mathrm{f}}$ & $0.995^{\mathrm{c}}$ & 0.000476 \\
ALGIN 1.0 $^{0.993^{\text {def }}}$ & $0.997^{\mathrm{ab}}$ & $0.994^{\mathrm{cd}}$ & $0.994^{\mathrm{cde}}$ & $0.996^{\mathrm{b}}$ & 0.000476 \\
\hline
\end{tabular}

${ }^{1}$ ALGIN is the inclusion percentage (\%) of two functional ingredients, sodium alginate and calcium lactate.

${ }^{\mathrm{a}-\mathrm{f}}$ Mean values lacking common superscripts differ $(p<0.05)$.

\section{Conclusions}

Little to no information regarding fresh pet food shelf-life studies currently exists within the research arena. Therefore, presentation of current findings provides a brief snapshot into the use of current ingredient technologies from the meat and food industries that may be considered as viable tools for formulating fresh pet food. The current results suggest that the inclusion of ALGIN on poultry co-product pet food combinations involving $\mathrm{CF}$ and/or WB can improve fresh surface color characteristics. However, the combination of $\mathrm{CF}$ or WB used can alter surface color lightness and redness regardless of ALGIN. Regardless, the current results suggest that ALGIN with either CF or WB can be utilized in the formulation of a fresh pet food. Additional research focused on the optimal shelf-life storage period of fresh pet food is needed.

Author Contributions: Conceptualization, C.W.S. and J.T.S.; methodology, M.P.W.; software, J.T.S.; validation, R.P.M., E.K.A. and M.R.P.; formal analysis, C.W.S. and J.T.S.; investigation, M.P.W., M.R.P., M.E.C., J.L.S. and T.M.R.; resources, J.T.S., C.W.S., R.P.M., E.K.A. and B.S.W.; data curation, T.M.R., H.R.S. and J.A.D.; writing—original draft preparation, M.P.W.; writing—review and editing, M.P.W., J.T.S. and C.W.S.; visualization, M.E.C. and G.A.A.-P.; supervision, J.T.S. and C.W.S.; project administration, J.T.S. All authors have read and agreed to the published version of the manuscript.

Funding: This research received no external funding.

Institutional Review Board Statement: Not Applicable. 
Informed Consent Statement: Not Applicable.

Data Availability Statement: Not Applicable.

Acknowledgments: Appreciation is extended to the Lambert-Powell Meats Laboratory at Auburn University with procurement of raw material and processing technologies. Furthermore, the authors are grateful for the support provided by Balchem Corp through technical expertise and ingredient formulations.

Conflicts of Interest: The authors declare no conflict of interest.

\section{References}

1. American Pet Products Association. Pet Industry Market Size, Trends \& Ownership Statistics. Available online: https://www. americanpetproducts.org/press_industrytrends.asp (accessed on 22 October 2021).

2. Ozdemir, S.; Yetilmezsoy, K.A. Mini literature review on sustainable management of poultry abattoir wastes. J. Mater. Cycles Waste Manag. 2020, 22, 11-21. [CrossRef]

3. Tijare, V.; Yang, F.; Kuttappan, V.; Alvarado, C.; Coon, C.; Owens, C. Meat quality of broiler breast fillets with white striping and woody breast muscle myopathies. Poult. Sci. 2016, 95, 2167-2173. [CrossRef] [PubMed]

4. Caldas-Cueva, J.P.; Owens, C.M. A review on the woody breast condition, detection methods, and product utilization in the contemporary poultry industry. J. Anim. Sci. 2020, 98, skaa207. [CrossRef] [PubMed]

5. Kuttappan, V.A.; Owens, C.M.; Coon, C.; Hargis, B.M.; Vazquez-Añon, M. Incidence of broiler breast myopathies at 2 different ages and its impact on selected raw meat quality parameters. Poult. Sci. 2017, 96, 3005-3009. [CrossRef] [PubMed]

6. Kuttappan, V.; Brewer, V.; Mauromoustakos, A.; McKee, S.; Emmert, J.; Meullenet, J.; Owens, C. Estimation of factors associated with the occurrence of white striping in broiler breast fillets. Poult. Sci. 2013, 92, 811-819. [CrossRef]

7. di Donfrancesco, B.; Koppel, K.; Swaney-Stueve, M.; Chambers, E. Consumer Acceptance of Dry Dog Food Variations. Animals 2014, 4, 313-330. [CrossRef]

8. Dunkley, C.S.; Carter, D.; Dunkley, K. Organic meat by-products for affiliated Food Industries. Org. Meat Prod. Process. 2012, 9, 53. [CrossRef]

9. Aldrich, G.; Meeker, D.L. Essential Rendering: All about the Animal By-Products Industry, 1st ed.; Meeker, D.L., Ed.; The National Renderers Association: Alexandria, VA, USA, 2006; pp. 167-168.

10. Seisun, D.; Zalesny, N. Strides in food texture and hydrocolloids. Food Hydrocoll. 2021, 117, 106575. [CrossRef]

11. McArdle, R.; Hamill, R. Utilisation of hydrocolloids in processed meat systems. Process. Meats 2011, 243-269. [CrossRef]

12. Pematilleke, N.; Kuar, M.; Rai Wai, C.T.; Adhikari, B.; Torley, P. Effect of the addition of hydrocolloids on beef texture: Targeted to the needs of people with dysphagia. Food Hydrocoll. 2021, 113, 106413. [CrossRef]

13. Diaz, R.F.S.; Acosta, A.; Starkey, C. Sodium Alginate and Calcium Lactate (Algin) Effect on Beef or Poultry Co-Product Blends Used in a Pet Jerky Product; Zamorano University: Tegucigalpa, Honduras, 2020. Available online: https://bdigital.zamorano.edu/handle/ 11036/6934 (accessed on 3 November 2021).

14. Xu, X.; Han, Q.; Shi, J.; Zhang, H.; Wang, Y. Structural, thermal and rheological characterization of bovine serum albumin binding with sodium alginate. J. Mol. Liq. 2020, 299, 112123. [CrossRef]

15. Qin, Y. Seaweed Hydrocolloids as Thickening, Gelling, and Emulsifying Agents in Functional Food Products. Bioact. Seaweeds Food Appl. 2018, 135-152. [CrossRef]

16. Means, W.J.; Schmidt, G.R. Algin/Calcium Gel as a Raw and Cooked Binder in Structured Beef Steaks. J. Food Sci. 1986, 51, 60-65. [CrossRef]

17. Means, W.; Clarke, A.; Sofos, J.; Schmidt, G. Binding, Sensory and Storage Properties of Algin/Calcium Structured Beef Steaks. J. Food Sci. 1987, 52, 252-256. [CrossRef]

18. Means, W.J.; Schmidt, G.R. Process for Preparing Algin/Calcium Gel Structured Meat Products. 1986. Available online: https:/ / patentimages.storage.googleapis.com/1e/b3/0c/ce6914690c445f/US4603054.pdf/ (accessed on 1 November 2021).

19. Kuttappan, V.A.; Lee, Y.S.; Erf, G.F.; Meullenet, J.-F.C.; McKee, S.R.; Owens, C.M. Consumers acceptance of visual appearance of broiler breast meat with varying degrees of white stripping. Poult. Sci. 2012, 91, 1240-1247. [CrossRef]

20. American Meat Science Association. Meat Color Measurement Guidelines; American Meat Science Association: Champaign, IL, USA, 2012.

21. Commission Internationale de 1' Eclairage. Recommendations on Uniform Color Spaces—Color Differences Equations, Psychometric Color Terms; C.I.E. Publication No. 15, Suppl. 2(E-1.3.1), 1972/(TC-1-3); Bureau Central de la CIE: Paris, France, 1978.

22. Buege, J.A.; Aust, S.D. Microsomal lipid peroxidation. Methods Enzymol. 1978, 52, 302-310. [CrossRef] [PubMed]

23. Bradley, R., Jr. Moisture and Total Solids Analysis. In Food Analysis, 4th ed.; Neilsen, S., Ed.; Springer Science: West Lafayette, IN, USA, 2010; pp. 101-102.

24. Zhuang, H.; Bowker, B. The wooden breast condition results in surface discoloration of cooked broiler pectoralis major. Poult. Sci. 2018, 97, 4458-4461. [CrossRef]

25. Dalle Zotte, A.; Tasoniero, G.; Puolanne, E.; Remignon, H.; Cecchinato, M.; Catelli, E.; Cullere, M. Effect of wooden breast appearance on poultry meat quality, histological traits, and lesions characterization. Czech J. Anim. Sci. 2017, 62, 51-57. [CrossRef] 
26. Sihvo, H.K.; Immonen, K.; Puolanne, E. Myodegeneration with Fibrosis and Regeneration in the Pectoralis Major Muscle of Broilers. Vet. Pathol. 2013, 51, 619-623. [CrossRef] [PubMed]

27. Soglia, F.; Laghi, L.; Canonico, L.; Cavani, C.; Petracci, M. Functional property issues in broiler breast meat related to emerging muscle abnormalities. Food Res. Int. 2016, 89, 1071-1076. [CrossRef]

28. Cavalcante da Rocha, T.; Moreira de Carvalho, L.; Soares, A.J.; Coutinho, D.C.; Olegario, L.S.; de Sousa Galvão, M.; Esétevez, M.; Madruga, M.S. Impact of chicken wooden breast quality and oxidative stability of raw and cooked sausages subjected to frozen storage. J. Sci. Food Agric. 2020, 100, 2630-2637. [CrossRef] [PubMed]

29. Wood, J.D.; Enser, M.; Fisher, A.V.; Nute, G.R.; Sheard, P.R.; Richardson, R.I.; Hughes, S.I.; Whittington, F.M. Fat deposition, fatty acid composition and meat quality: A review. Meat Sci. 2008, 78, 343-358. [CrossRef] [PubMed]

30. Ferreira, V.C.S.; Morcuende, D.; Madruga, M.S.; Hernández-López, S.H.; Silva, F.A.P.; Vetanas, S.; Estévez, M. Effect of precooking methods on the chemical and sensory deterioration of ready-to-eat chicken patties during chilled storage and microwave reheating. J. Food Sci. Technol. 2016, 53, 2760-2769. [CrossRef]

31. Greene, B.E.; Cumuze, T.H. Relationship Between TBA Numbers and Inexperienced Panelists' Assessments of Oxidized Flavor in Cooked Beef. J. Food Sci. 1982, 47, 52-54. [CrossRef]

32. Campo, M.M.; Nute, G.R.; Hughes, S.I.; Enser, M.; Wood, J.D.; Richardson, R.I. Flavour Perception of Oxidation in Beef. Meat Sci. 2006, 72, 303-311. [CrossRef] [PubMed]

33. Kanner, J. Oxidative Processes in Meat and Meat Products: Quality Implications. Meat Sci. 1994, 36, 169-189. [CrossRef]

34. Aquirre, M.E.; Owens, C.M.; Miller, R.K.; Alvarado, C.Z. Descriptive Sensory and Instrumental Texture Profile Analysis of Wooden Breast in Marinated Chicken. Poult. Sci. 2018, 97, 1456-1461. [CrossRef]

35. Madruga, M.S.; da Roacha, T.C.; de Carvalho, L.M.; Sousa, A.M.B.L.; de Sousa Neto, A.C.; Coutinho, D.C.; de Carvalho Ferreira, A.S.; Soares, A.J.; de Sousa Galvão, M.; Ida, E.I.; et al. The impaired quality of chicken affected by the wooden breast myophathy is counteracted in emulsion-type sausages. J. Food Sci. Technol. 2019, 56, 1380-1388. [CrossRef]

36. Petracci, M.; Mudalal, S.; Bonfiglio, A.; Cavani, C. Occurrence of white stripping under commercial conditions and its impact on breast meat quality in broiler chickens. Poult. Sci. 2013, 92, 1670-1675. [CrossRef]

37. Ozkececi, R.B.; Karayaya, M.; Yilmaz, M.T.; Saricoban, C.; Ockerman, H.W. The Effect of Carcass Part and Packaging Method on the Storage of Mechanically Deboned Chicken Meat. J. Muscle Foods 2008, 19, 288-301. [CrossRef]

38. Oliveira, R.F.D.; Fávero, M.S.; Mello, J.L.M.D.; Ferrari, F.B.; Cavalcanti, E.N.F.; Souza, R.A.D.; Pereira, M.R.; Giampietro-Ganeco, A.; Villegas-Cayllahua, E.A.; Fidelis, H.D.A.; et al. Effects of Storage on Quality Traits of Sausages Made with Chicken Breast Meat Affected by Wooden Breast. Animals 2021, 11, 513. [CrossRef] [PubMed]

39. Chen, G.; Liu, B.; Zhang, B. Characterization of Composite Hydrocolloid Film Based on Sodium Cellulose Sulfate and Cassava Starch. J. Food Eng. 2014, 125, 105-111. [CrossRef] 